\title{
Students - Future Teachers' Knowledge and Attitudes towards Migrations of Species and Diseases Caused by Insects
}

\author{
Katarzyna Potyrala ${ }^{1}$, Karolina Czerwiec ${ }^{1, *}$, Malgorzata Klys ${ }^{2}$ \\ ${ }^{1}$ Faculty of Social Sciences, Institute of Educational Sciences, Pedagogical University of Cracow, Poland \\ ${ }^{2}$ Faculty of Exact and Natural Sciences, Institute of Biology, Pedagogical University of Cracow, Poland
}

Received September 8, 2019; Revised October 31, 2019; Accepted November 11, 2019

Copyright $\subseteq 2020$ by authors, all rights reserved. Authors agree that this article remains permanently open access under the terms of the Creative Commons Attribution License 4.0 International License

\begin{abstract}
The aim of the research was to diagnose the knowledge and attitudes of the students-future teachers, on diseases caused by insects and relationship between migration of people and the spread of diseases. It was assumed that students-future teachers: have a wide range of knowledge about diseases caused by insects; recognize that there is a correlation between the influx of migrants and the threat of the spread of infectious diseases, which were rare so far in European countries or have not been presented at all. Research was carried out with the use of diagnostic survey and the research tool - questionnaire (Thurstone scale). Results of the research showed that 1120 students-future teachers: 504 of Polish and 616 of French universities have a high level of knowledge in the field of infectious diseases (at the level of $62 \%$ to $92 \%$ ). However, $90 \%$ of respondents express concern about outbreak of bacterial and viral diseases in connection with the possibility of uncontrolled human migrations. Such students' attitudes can have an effect on the way of transformation of educational contents on migration of different populations and the interaction between them, which should be tested for deeper understanding of teaching contents.
\end{abstract}

Keywords Insects, Attitudes, Teacher Training

\section{Introduction}

In nature, there are different types of organisms spreading. They can be active, passive and active-passive. For the animal world, mainly active movement is characteristic, to which individual species have appropriate locomotor adaptation and orientation organs in space. A common way of spreading the organism is passive dispersion. In the means of transport, it may be by wind and air currents (anemochorous dispersion) water (hydrochorous dispersion) and animals that carry tiny organisms (zoochorous dispersion). For example, some insects attach to feathers, animal hair vectors are moving with them sometimes for the long distances. This is called epizoochoria - transported by the outer surface. From the biogeographical point of view zoochoria it is one of the basic mechanisms of interregional and even intercontinental spread of organisms. The form of zoochorous dispersion is antropochoria, which is the spread of organisms and species by man. Anthropogenic spread of organisms is done by three ways: by opening of migration routes, transmission and an introduction. They lead to the extension of the original ranges of introduced species and shrinking ranges of native species [20] [26].

The air dispersion is considered to be the most important type of dispersion of actively flying insects, and those which are transferred passively (e.g., Hymenoptera sawflies, Coleoptera beetles, transmitted during heavy tornados) .In the $60 \mathrm{~s}$, entomologists from Canada and the USA studied the air dispersion of insects. Gressit [21] and Gressit and Yashimoto [22] installed special catching devices on airplanes which were flying over the Pacific Ocean. They caught more than two thousand insects: most Diptera, Homoptera and Hymenoptera. Because of the air method, the insects populated the oceanic islands and they were moving through the sea straits [37]. Often migration of insects is held at high altitudes, hundreds of meters above the Earth (the planetary boundary layer (PBL) and then the directions of migration are largely dependent on the wind [15] [16].

By bringing into, from the earliest years, insect and pests living in stored grains food products have been spreading. The original place of their occurrence was nest of birds, rodents and insects, which developed on dead plant or 
animal material. When the man began to lead a settled life and at the same time collected the crops to survive adverse conditions, pests began to appear in the storage rooms. In the last few years widespread exchange of goods, improvement of communication, and even tourism between countries and continents caused that many species of insects, including pests of stored cereal grains and foods, living in a tropical climate and subtropical, have been brought into accidentally to the countries of moderate climate. The first bringing into storage insects to Europe took place in the eighteenth century and followed the transport cereals, food commodities of plant origin, mainly by sea [32] [27]. Later pests were brought into secondarily from barns and port warehouses to mills, wholesale companies and food - processing plants. For a long time insects, food pests are cosmopolitan organisms. They can fill food at various stages of its production, and during its transport, storage in warehouses and grocery stores.

Insects may enter into new areas of products of plant origin on the packaging, seeds, fruits and live plants. It is on decorative plants, massively imported into European countries most insects have been found, for example Tobacco Whitefly (Phyllonorycter robiniella) dangerous pest plants grown in greenhouses. The main reason for the spread of the whitefly is an international trade seedling of poinsettia (Euphorbia pulcherrima Willd. Ex Klotzsch). Currently, the real threat to the cultivation of tomato in Europe is also tomato leaf miner moth (Tuta absoluta Povolny) spreading in the Mediterranean countries, where losses are estimated in the harvest of even 25\% [28]. You should expect rapid adaptation of these species of insects, because the plants on which the insects thrive are propagated in greenhouses where the insects have favorable conditions for the life and development similar to those occurring in the warm climate zone.

With regard to the human population in the history, the migration has always occurred and on the one hand it was systematic, regular and stemmed from personal preference or conditioned by individuals, on the other hand, its causes were sudden and irregular [30]. In connection with the increasing migration of people ${ }^{1}$, a legitimate question arises, which was the purpose of the study, whether there is knowledge and awareness about the diseases caused by insects and whether there may be a link between migration of people and the spread of diseases, especially infectious diseases. In addition, the attitudes of the students of teaching specialization towards the fact of the influx of immigrants to Europe were determined. Research issues

\footnotetext{
1 Until the mid-80s the number of asylum seekers (common term referring to people applying for refugee status, the so-called 'Syrian refugees') does not exceed 100 thousand per year on a global scale, in 2001 - about 600 thousand, in 2014 - 866 thousand registered applicants, 184 thousand granted refugee status or another form of protection, 825 refugee applications were filed in European countries, the highest in Germany $(20 \%)[30$, p. 6]. Every year, to the EU countries 1-2 million immigrant come legally from outside the area - 1.4 million in 2014 [30, p. 7].
}

stem from the fact that, despite the small scale of the influx of foreigners to Poland, "the crisis refugee" was strongly present in the media [6]. The lively debate of media about refugees, seemed to refer to earlier fears and prejudices against immigrants [6]. Michael Bilewicz [6] detects the sources of the crisis of attitude in connection with the migration of the population and believes that the increased empathy and less fear translate into an overall improvement in attitudes towards immigrants. The possibilities of overcoming the crisis are holistic education and integration.

The main objective of the research was the diagnosis of students - future teachers' knowledge and attitudes towards the diseases caused by insects and students' understanding of the links between migration of people and the spread of diseases, especially caused by insects.

\section{Materials and Methods}

\subsection{Research Methodology}

The following research problems were formulated:

1. What is the level of students-future teachers' knowledge of diseases caused by insects?

2. What are the attitudes of students-future teachers towards the phenomenon of migration of the population and its relationship to the spread of disease?

\subsection{Research Hypotheses}

1. Students have a wide range of knowledge about diseases caused by insects.

2. Students recognize that there is a correlation between the influx of migrants to Europe and the threat of the spread of infectious diseases, which were rare so far in European countries or have not been presented at all.

Research was carried out in 2013-2018. The diagnostic survey and questionnaire (Thurstone attitudes scale, equal appearing intervals) were used. Research method and tool were selected in accordance with the guidelines of Babbie [3]. In the diagnostic survey 1120 students: 504 students-future teachers from Polish universities and 616 students-future teachers from French universities took part. The online survey was filled by students of various faculties, but all from the teaching specialization. Returning questionnaires were also received from students from Germany, Turkey and Czech Republic, but the research sample turned out to be unrepresentative. Therefore, it was decided to compare the responses of Polish and French students, who received the most feedback in a comparable number.

First part of the questionnaire was checking the scope of students' knowledge of diseases caused by insects. Second 
part of survey included 20 statements linked to students' attitudes towards migrations in connection with the human diseases.

The broadest range of statements that characterize negative and positive attitudes was developed. The prepared list of statements was presented to the experts competent judges who assessed them. On the basis of this assessment, 20 best-case statements are selected.

List of research methods and tools selected in accordance with the guidelines of Babbie [3] are included in Table 1.

Table 1. Research methods and tools

\begin{tabular}{|c|c|}
\hline Research methods & Research tools \\
\hline analysis ( literature) & $\begin{array}{c}\text { original guide to the analysis of } \\
\text { documents }\end{array}$ \\
\hline $\begin{array}{c}\text { analysis of media } \\
\text { messages }\end{array}$ & $\begin{array}{c}\text { original guide to the analysis of media } \\
\text { messages }\end{array}$ \\
\hline diagnostic survey & $\begin{array}{c}\text { questionnaire (scale of attitudes by } \\
\text { Thurstone) }\end{array}$ \\
\hline
\end{tabular}

\section{Results}

One part of the survey was checking the scope of students' knowledge of diseases caused by insects. The vast majority of respondents showed a high level of knowledge in this field. Correct answer was given by $62 \%$ to $93 \%$ depending on the issue. Detailed data are included in Table 2.

According to the majority of students $(90 \%$ of Polish students and $81 \%$ of French students) there is a risk of spreading diseases in connection with the arrival of refugees. In their opinion, in such a large group of immigrants there is a risk of rapid multiplication of bacteria, viruses and fungi, and the spread of diseases that could threaten local communities. Therefore, refugees should undergo quarantine after arriving in Europe and Europeans should be vaccinated for the characteristic diseases occurring in countries from which immigrants come. The $69 \%$ of Polish students and $75 \%$ of French students of respondents believe that immigrants do not respect the rules of hygiene and so may pose a threat to Europeans. Fear of outbreak of diseases, which were not previously presented in Europe, was expressed by the $77 \%$ of Polish students and $82 \%$ of French students.

According to the $52 \%$ of the Polish students and $60 \%$ of French students, they believe that the diseases occurring in Europe pose a threat to immigrants. The $53 \%$ of the Polish students and $65 \%$ of French students believe that bacteria, viruses and fungi typical for European countries are a threat to immigrants - why immigrants should be vaccinated for the characteristic diseases of Europe (53\% of Polish students and $45 \%$ of French students). On the other hand, the $49 \%$ of Polish students and $40 \%$ of French students (including those who have demonstrated a wide range of knowledge on issues related to diseases caused by insects), declared that they can characterize such diseases as tuberculosis, measles, polio, viral hepatitis, recognize their symptoms and know the preventive measures. Detailed results are included in Figure 1.

Table 2. The scope of the students' knowledge on issues related to diseases caused by insects

\begin{tabular}{|c|c|c|c|c|c|}
\hline & Issue & \multicolumn{2}{|c|}{ Polish students } & \multicolumn{2}{c|}{ French students } \\
\cline { 3 - 5 } & correct answers (\%) & wrong answers (\%) & correct answers (\%) & wrong answers (\%) \\
\hline $\mathbf{1}$ & $\begin{array}{c}\text { Trade, efficient communication, } \\
\text { tourism. }\end{array}$ & 84 & 16 & 80 & 20 \\
\hline $\mathbf{2}$ & $\begin{array}{c}\text { Insects as a source of parasites that can } \\
\text { infect local populations. }\end{array}$ & 93 & 7 & 90 & 10 \\
\hline $\mathbf{3}$ & $\begin{array}{c}\text { Economic and economical losses } \\
\text { caused by invasive species. }\end{array}$ & 92 & 16 & 75 & 7 \\
\hline $\mathbf{4}$ & $\begin{array}{c}\text { Parasitic species and pests they } \\
\text { parasitize the human body, transfer } \\
\text { plant pathogens, human and animal } \\
\text { diseases. }\end{array}$ & 84 & 38 & 63 & 25 \\
\hline $\mathbf{5}$ & $\begin{array}{c}\text { Housefly as a carrier of pathogens } \\
\text { microorganisms. }\end{array}$ & 62 & 26 & 81 & 35 \\
\hline $\mathbf{6}$ & $\begin{array}{c}\text { Pathogens spread by mosquitoes in } \\
\text { connection with the expansion of range } \\
\text { of distribution, due to global warming. }\end{array}$ & 74 & & 75 \\
\hline
\end{tabular}




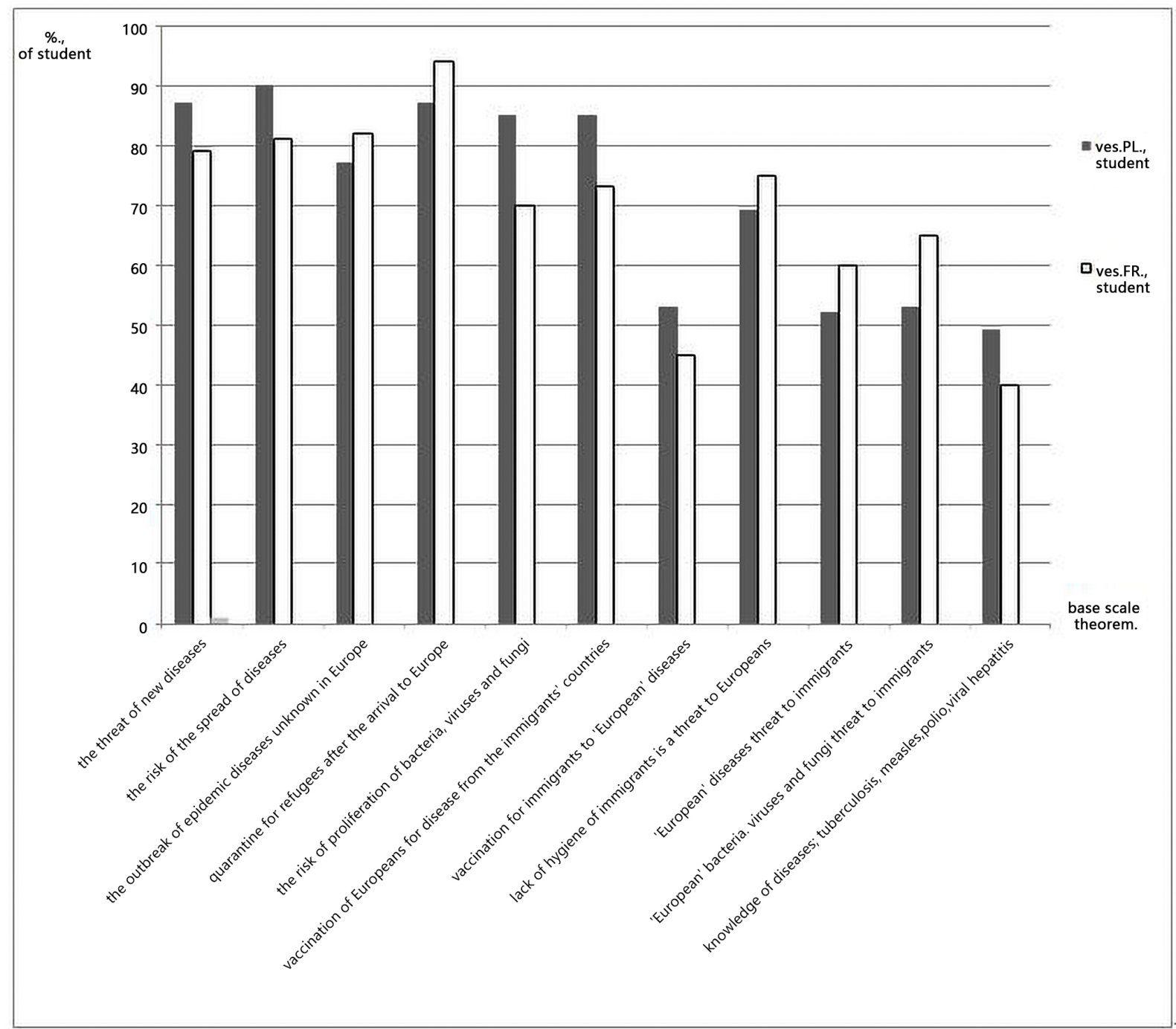

Figure 1. Attitudes of students towards the relationship between the disease spread and the influx of immigrants to Europe

The research also applies to the content of the news media about the opinion concerning immigrants. The purpose of respondents was to express an opinion on them, and make it clear whether the text awakens in them any concerns. Some of the messages in the presented research confirm the risk of diseases previously unknown in Europe, which could occur (or even appear) due to the inflow of immigrants and cause epidemics. While the other ones contained information about functioning of health service, which ensures that no European country was threatened by "exotic" disease. Students' opinions (audited by the scale of attitudes by Thurstone) were grouped into thematic areas.
They are presented in Tables 3-7. Each student could express more than one opinion on each news media (and the original statements of the students were retained).

Respondents expressed their views critically about the emergence of diseases previously unknown in Europe, which could spread through immigrant (Table 3 ). The most frequent comments were: 1 / prevention and regular testing can reduce the risk of disease, but not eliminate it entirely; $2 /$ possible disease may spread outside the camp, because with so many people, there is no possibility to examine the all. 
Table 3. Student opinions on the health consequences of the emergence of immigrants in Europe - disease

\begin{tabular}{|c|c|c|}
\hline \multirow{2}{*}{ Opinions } & \multicolumn{2}{|c|}{ Number of opinions } \\
\hline & Polish students & French students \\
\hline $\begin{array}{l}\text { Prevention and regular testing can reduce the risk, but not eliminate it entirely, } \\
\text { and the disease may spread outside the camp. With such a large number of people, } \\
\text { there is no possibility to examine all of them. }\end{array}$ & 90 & 101 \\
\hline $\begin{array}{l}\text { There can be diseases which have been eradicated or the new ones can be } \\
\text { developed. That Recurrence of serious illness arouses anxiety is a threat to the } \\
\text { continent. }\end{array}$ & 74 & 88 \\
\hline $\begin{array}{l}\text { We do not really know what disease can be brought by refugees and how to } \\
\text { prevent them. New types of viruses can become for us a real threat. }\end{array}$ & 68 & 75 \\
\hline $\begin{array}{l}\text { Climate does not matter if that was a lot of carriers of dangerous diseases. } \\
\text { Diseases mutate, adapt to new environments. This raises concerns. }\end{array}$ & 64 & 69 \\
\hline $\begin{array}{l}\text { Immigrants carry diseases unknown to the end of the doctors who should } \\
\text { familiarize themselves with the symptoms of characteristic diseases of } \\
\text { immigrants; it will be helpful when using rapid prevention. }\end{array}$ & 60 & 54 \\
\hline $\begin{array}{l}\text { Random testing of immigrants may be failure detection of diseases. Precaution } \\
\text { and examination should be increased. }\end{array}$ & 54 & 59 \\
\hline $\begin{array}{l}\text { There is a risk of more frequent infectious diseases, because it will be difficult to } \\
\text { examine all immigrants. }\end{array}$ & 38 & 49 \\
\hline $\begin{array}{l}\text { The countries from which the refugees come are on the lower level of civilization, } \\
\text { there is different climate, so it is a threat. }\end{array}$ & 34 & 45 \\
\hline $\begin{array}{l}\text { Refugees should be thoroughly checked in terms of health. No wonder it is the } \\
\text { fear of disease posed by them. Europe is not prepared for it. }\end{array}$ & 30 & 40 \\
\hline $\begin{array}{l}\text { The low risk of outbreak does not mean the exclusion. There is still a risk of } \\
\text { contracting a disease that does not exist in Europe; therefore, you should not } \\
\text { accept refugees. }\end{array}$ & 30 & 44 \\
\hline $\begin{array}{l}\text { There is no certainty that the quarantine is carried out in detail. The conditions in } \\
\text { the temporary camps provide a cure for sick refugees. Despite this, I have } \\
\text { concerns. }\end{array}$ & 24 & 20 \\
\hline $\begin{array}{l}\text { Anyone returning from their visit to the Asian country may be a carrier of a } \\
\text { contagious disease. The control of incoming people should be increased. }\end{array}$ & 24 & 32 \\
\hline $\begin{array}{l}\text { In Europe, begin to occur previously unknown disease with which we have } \\
\text { contact, and which are a threat to health. }\end{array}$ & 20 & 31 \\
\hline $\begin{array}{l}\text { Insufficient control of medical immigrants increases the risk of dangerous, } \\
\text { unknown diseases to European, }\end{array}$ & 20 & 29 \\
\hline $\begin{array}{l}\text { With all the "refugees," no one is able to examine them in order to estimate the } \\
\text { probability of spreading of these diseases as low. }\end{array}$ & 20 & 19 \\
\hline $\begin{array}{l}\text { I believe that the climatic conditions in Europe contribute to the development of } \\
\text { diseases and bacteria. Not many people are vaccinated additionally, because the } \\
\text { vaccines are expensive. }\end{array}$ & 20 & 22 \\
\hline $\begin{array}{l}\text { Everyone should realize that diseases appear along with immigrants and the state } \\
\text { should prevent the spread of these diseases. }\end{array}$ & 16 & 29 \\
\hline $\begin{array}{l}\text { This is very worrying because casualties are recorded. People should be tested } \\
\text { before they come to a new country because they migrate between countries. }\end{array}$ & 14 & 19 \\
\hline $\begin{array}{l}\text { Medical personnel have to be prepared for any unusual disease because many of } \\
\text { them are transmitted by immigrants. }\end{array}$ & 12 & 8 \\
\hline Such cases raise concerns among the public, which is normal. & 10 & 5 \\
\hline $\begin{array}{l}\text { Europe is not prepared for unusual diseases that can be brought by immigrants, } \\
\text { because such diseases are more difficult to diagnose and cure. }\end{array}$ & 8 & 14 \\
\hline $\begin{array}{l}\text { We should not accept refugees to Europe, because they can bring diseases that } \\
\text { have not occurred there for a long time. }\end{array}$ & 4 & 7 \\
\hline
\end{tabular}

Students also expressed concern about the possibility of an outbreak of bacterial and viral diseases, even in the more stringent health checks of immigrants or the administration of vaccines (Table 4). The most frequent comments included: 1/ uncontrolled influx of immigrants can lead to outbreaks of dangerous diseases, which are unknown in Europe, which could lead to an epidemic on a large scale; 2/ no one will be able to control the vaccination and the immigrants do not apply to the vaccination calendars. 
Table 4. Student opinions on the health consequences of the emergence of immigrants in Europe - epidemics, and vaccination

\begin{tabular}{|c|c|c|c|}
\hline \multirow{2}{*}{ Issue } & \multirow{2}{*}{ Opinions } & \multicolumn{2}{|c|}{$\mathrm{Nr}$ of opinions } \\
\hline & & Polish students & French students \\
\hline \multirow{5}{*}{ Epidemic } & $\begin{array}{l}\text { The uncontrolled influx of immigrants can lead } \\
\text { to outbreaks of dangerous diseases, unknown in } \\
\text { Europe, which could lead to an epidemic on a } \\
\text { large scale. }\end{array}$ & 144 & 160 \\
\hline & $\begin{array}{l}\text { The larger number of refugees, the greater the } \\
\text { risk of an outbreak of diseases. This is a serious } \\
\text { threat to Europe. }\end{array}$ & 122 & 143 \\
\hline & $\begin{array}{l}\text { The fact that there has been no outbreak does not } \\
\text { mean that it will not happen in the future. With } \\
\text { such a large number of immigrants a threat is } \\
\text { increasing rapidly. }\end{array}$ & 60 & 87 \\
\hline & $\begin{array}{l}\text { Uncontrolled arrival of so many immigrants } \\
\text { could lead to dangerous consequences disease } \\
\text { outbreaks. }\end{array}$ & 50 & 59 \\
\hline & $\begin{array}{l}\text { If the refugees at this pace will flow to Europe, it } \\
\text { will be no control over disease. Then the } \\
\text { epidemic could become the pandemic. }\end{array}$ & 48 & 64 \\
\hline \multirow{8}{*}{ Vaccination } & $\begin{array}{l}\text { No one would be able to control them, and there } \\
\text { is no certainty that they would follow the } \\
\text { vaccination calendars. }\end{array}$ & 70 & 67 \\
\hline & $\begin{array}{l}\text { Vaccines change nothing and innocent people } \\
\text { will take serious consequences. I do not believe } \\
\text { in ensuring Sanitary Inspectorate. This raises } \\
\text { concerns. }\end{array}$ & 28 & 20 \\
\hline & $\begin{array}{l}\text { If vaccinations are not fully effective, do not } \\
\text { enter an emergency situation of millions of } \\
\text { people. }\end{array}$ & 26 & 10 \\
\hline & $\begin{array}{l}\text { Immigrants can transmit dangerous diseases to } \\
\text { Europe. It is not said that they will have certain } \\
\text { guarantees for testing and vaccination. }\end{array}$ & 20 & 35 \\
\hline & $\begin{array}{l}\text { Characteristic diseases of Europeans may also } \\
\text { threaten the immigrants who should be } \\
\text { vaccinated. }\end{array}$ & 12 & 20 \\
\hline & $\begin{array}{l}\text { Immigrants should be vaccinated against } \\
\text { diseases that do not exist in Europe, and which } \\
\text { they may bring with them. }\end{array}$ & 10 & 3 \\
\hline & $\begin{array}{l}\text { The difference in European/Syrian genotype } \\
\text { may cause the vaccine ineffective. }\end{array}$ & 10 & 17 \\
\hline & $\begin{array}{l}\text { Vaccination is a good solution, but I do not know } \\
\text { if this is enough to lower the level of the risk. }\end{array}$ & 6 & 2 \\
\hline
\end{tabular}

A clear division in the opinions of students appeared in the issue of compliance by immigrants' rules of personal hygiene. Some of the students are of the opinion that the lack of hygiene among refugees will certainly generate the spread of bacteria, viruses and fungi in European countries. The second part of the respondents believe that the submission to, quarantine, testing and possible vaccinations eliminates possible risks (Table 5). 
Table 5. Students opinions on the personal hygiene of immigrants

\begin{tabular}{|c|c|c|}
\hline \multirow{2}{*}{ Opinions } & \multicolumn{2}{|c|}{ Nr of opinions } \\
\hline & Polish students & French students \\
\hline \multicolumn{3}{|l|}{ CONCERNS } \\
\hline $\begin{array}{l}\text { Contamination left by refugees, increases the risk of transmission of disease } \\
\text { not just by people but also by animals. }\end{array}$ & 44 & 58 \\
\hline $\begin{array}{l}\text { Disease transmission does not concern mainly tourists. The risk is increased } \\
\text { by refugees who are weak, have poor hygiene by the situation in which they } \\
\text { are located. If it were not refugees, we could have avoided such situations. }\end{array}$ & 44 & 52 \\
\hline $\begin{array}{l}\text { Feces and litter of immigrants are dangerous, so they should be aware. They } \\
\text { come to Europe in bad conditions; such a solution would be good. }\end{array}$ & 40 & 35 \\
\hline $\begin{array}{l}\text { Refugees entering into Europe should take our habits when it comes to } \\
\text { personal hygiene, because it exposes us to danger. Europe should close their } \\
\text { borders to refugees, if they do not comply with the applicable rules and the } \\
\text { law. }\end{array}$ & 30 & 49 \\
\hline $\begin{array}{l}\text { Poor living conditions affect the health of refugees, doctors and people who } \\
\text { need to be prepared for it. }\end{array}$ & 24 & 32 \\
\hline $\begin{array}{l}\text { We all know (I hope) what these people leave behind, and what the } \\
\text { consequences are;. }\end{array}$ & 22 & 15 \\
\hline $\begin{array}{l}\text { The idea of Germans about multicultural toilets on the routes is grotesque. } \\
\text { Supposed to help, but if any of immigrants would like to use it? }\end{array}$ & 14 & 9 \\
\hline Many illegal immigrants are not subjected to supervision, also sanitary one. & 14 & 21 \\
\hline \multicolumn{3}{|l|}{ LACK OF CONCERNS } \\
\hline $\begin{array}{l}\text { If immigrants are under observation, they will be examined and vaccinated, } \\
\text { the risk of the spread of these diseases is low. }\end{array}$ & 100 & 89 \\
\hline It does not raise my concerns. & 38 & 35 \\
\hline $\begin{array}{l}\text { The arrival of refugees will not cause in Europe some terrible diseases } \\
\text { comingout, and the epidemic does not threaten us. }\end{array}$ & 12 & 20 \\
\hline $\begin{array}{l}\text { In Europe, there are also diseases such as measles, tuberculosis and hepatitis, } \\
\text { whose treatment is known to us. }\end{array}$ & 8 & 17 \\
\hline $\begin{array}{l}\text { Diseases are dangerous, but there is no concern as long as we have the means } \\
\text { to fight them, e.g. flu. }\end{array}$ & 8 & 5 \\
\hline It does not raise my concerns, if these principles are actually complied with. & 4 & 2 \\
\hline Providing aid of modern medicine. & 4 & 4 \\
\hline $\begin{array}{l}\text { Immigrants are temporarily isolated, so there is little chance of getting } \\
\text { disease to Europe. }\end{array}$ & 4 & 9 \\
\hline $\begin{array}{l}\text { Because of poor sanitation of refugees, they can have health problems, but if } \\
\text { they have to be vaccinated for various diseases rather it should not be a big } \\
\text { problem. }\end{array}$ & 4 & 3 \\
\hline
\end{tabular}

Students also expressed their general opinions on immigrants (Table 6). Anti-immigrant attitude (which is definitely stronger) mainly relates to the fear of the dangers that immigrants bring: diseases; financial motives rather than the war; the desire to spread Islam in Europe; lack of interest in the assimilation of European culture. In turn, pro-immigrants attitude (Table 7) manifests in the opinions alleging members of the society and the media premature spreading of panic, as well as paying particular attention to the fact that the risk of a particular disease can always occur - regardless of whether Europe will take in immigrants or will not. 
Table 6. Anti-immigrant attitudes of students

\begin{tabular}{|c|c|c|}
\hline \multirow{2}{*}{ Opinions } & \multicolumn{2}{|c|}{ Nr of opinions } \\
\hline & Polish students & French students \\
\hline $\begin{array}{l}\text { Because of the disease, medical safety rules in receiving refugees should be tightened. We } \\
\text { should not fear that our homes will bring in people who can infect us and our families. }\end{array}$ & 64 & 50 \\
\hline $\begin{array}{l}\text { People can help in any other way than by bringing them to Europe. In Africa, in the countries } \\
\text { unoccupied by war, there are places for such people. You can always provide such assistance } \\
\text { to the refugees there; they do not have to leave their continent. }\end{array}$ & 50 & 69 \\
\hline $\begin{array}{l}\text { They should be subjected to vaccination, but the refugees are very reluctant to undergo any } \\
\text { testing, because after it, there must be verification of personal data of the patient. }\end{array}$ & 41 & 58 \\
\hline Help them on the spot, but do not take in. & 34 & 35 \\
\hline $\begin{array}{l}\text { Islam will never comply with European principles, and they form a state within a state, and } \\
\text { our countries are occupied by immigrants who impose your laws and principles. }\end{array}$ & 32 & 26 \\
\hline One should close the borders as Hungary did. & 30 & 23 \\
\hline $\begin{array}{l}\text { Bending reality and showing immigrants in a good light. Immigrants do not want to undergo } \\
\text { testing because doctors need to verify the patient and not all refugees go to the camps. }\end{array}$ & 30 & 42 \\
\hline $\begin{array}{l}\text { If a situation arises where all countries really will have to accept refugees, I agree that those } \\
\text { people who are coming are healthy and in need. Because most of the incoming people are } \\
\text { young men, who run away from the situation in the country. }\end{array}$ & 28 & 31 \\
\hline $\begin{array}{l}\text { Let them not come to Europe. Diseases in Europe are not as scary for them as the ones that } \\
\text { they can bring. }\end{array}$ & 28 & 25 \\
\hline $\begin{array}{l}\text { As to preparation of Europe to accommodation of refugees, perhaps we can all see the } \\
\text { consequences. It's hard to say that any state is prepared for vaccination and treatment. The } \\
\text { number of refugees is large and it will be difficult to have everything under control. }\end{array}$ & 24 & 39 \\
\hline $\begin{array}{l}\text { I hope them not to go to all European countries, and if they succeed, let's hope that they will be } \\
\text { properly examined. }\end{array}$ & 24 & 38 \\
\hline Political correctness creates pro-immigrants attitudes. & 20 & 36 \\
\hline Support treatment, but separate from the citizens, or do not take refugees. & 20 & 17 \\
\hline $\begin{array}{l}\text { The Western countries which are opened for accommodating refugees have already paid the } \\
\text { consequences. Only in the attacks are killed innocent citizens, not to mention the risk of } \\
\text { diseases. People are terrified and intimidated so that their concerns are fully justified. }\end{array}$ & 20 & 29 \\
\hline $\begin{array}{l}\text { Immigrants should not have to come to Europe because they are representatives of a hostile } \\
\text { culture. }\end{array}$ & 20 & 34 \\
\hline $\begin{array}{l}\text { We are not able to educate such a large number of people. These are false theories. } \\
\text { Immigrants are people of different cultures, beliefs and values. They will never want to } \\
\text { completely win over with Europe on any plane of life. The solution presented by Germans } \\
\text { will not change anything, because cultural diversity is too large and immigrants are not able to } \\
\text { adjust to our culture. }\end{array}$ & 20 & 33 \\
\hline $\begin{array}{l}\text { Greece has not secured appropriately in terms of outbreak. It should take precautions, e.g. } \\
\text { reducing the number of immigrants. Now Greece has to invest more budget funds in order to } \\
\text { prevent epidemics. }\end{array}$ & 18 & 22 \\
\hline It can arouse aversion to refugees, which is already very strong. & 18 & 20 \\
\hline These effects will not be executed; it is only an attempt to calm the public. & 16 & 33 \\
\hline $\begin{array}{l}80 \% \text { of immigrants are young men, who instead of fighting in their own country 'conquer' } \\
\text { Europe. }\end{array}$ & 16 & 45 \\
\hline $\begin{array}{l}\text { Europe is not prepared to accept immigrants. You can see the helplessness of services that } \\
\text { need to be dealt with immigrants. }\end{array}$ & 16 & 37 \\
\hline $\begin{array}{l}\text { Not surprisingly, the Belgians are troubled and become resentful of the government. } \\
\text { Theoretically, people do not bear the grudge towards the refugees, and furthermore, they do } \\
\text { not refuse to help them. In practice, it is probably different. }\end{array}$ & 16 & 0 \\
\hline $\begin{array}{l}\text { Immigrants are a threat to their migration route. You have to show what problems immigrants } \\
\text { bring. }\end{array}$ & 14 & 7 \\
\hline I am for all the activities aiming at strengthening safety. & 12 & 5 \\
\hline $\begin{array}{l}\text { Writing that immigrants is not a threat to society, falsification of reality. Misinformation and } \\
\text { propaganda. }\end{array}$ & 10 & 3 \\
\hline What do they want to look for in Europe? & 10 & 0 \\
\hline People should be definitely more careful in dealing with refugees. & 10 & 0 \\
\hline $\begin{array}{l}\text { Why so many of them come if they are sick? They are choosing the exhausting journey with } \\
\text { the hope that they will succeed. They expose themselves to death, thereby bringing threats to } \\
\text { us. }\end{array}$ & 6 & 0 \\
\hline It looks a bit like a chemical weapon. & 4 & 0 \\
\hline
\end{tabular}


Table 7. Pro - immigration attitudes of students

\begin{tabular}{|c|c|c|}
\hline \multirow{2}{*}{ Opinions } & \multicolumn{2}{|c|}{$\mathrm{Nr}$ of opinions } \\
\hline & Polish students & French students \\
\hline Unnecessary panic. & 50 & 43 \\
\hline $\begin{array}{l}\text { It does not raise concerns. Vaccines are the correct solution. It should avoid the } \\
\text { risk of a variety of infectious diseases in the country. }\end{array}$ & 50 & 40 \\
\hline Every examined person lowers the risk of diseases. & 40 & 45 \\
\hline $\begin{array}{l}\text { People are panicking while they even do not know who is coming and what is } \\
\text { their state of health. Be prepared for anything, but do not panic. Media can make } \\
\text { the small problem become serious threat. }\end{array}$ & 30 & 41 \\
\hline These are still speculations and conjectures. Now what counts is the true facts. & 24 & 29 \\
\hline People in Europe in terms of health are safe. & 24 & 17 \\
\hline It is beyond my concerns because the epidemic does not apply to my country. & 20 & 34 \\
\hline In Europe, and without immigrants, we have tuberculosis. & 20 & 32 \\
\hline Unnecessary panic can happen always, may well have happened to us on the trip. & 19 & 23 \\
\hline It is beyond my concerns, which are the result of war and poverty. & 19 & 12 \\
\hline Not everything that happens in another country, has place in our country. & 18 & 17 \\
\hline Such healthcare should be sufficient. & 17 & 22 \\
\hline Vaccination for tuberculosis is obligatory, which reduces the risk of disease. & 16 & 12 \\
\hline $\begin{array}{l}\text { Propaganda in favor of pharmaceutical companies. Some of the diseases imported } \\
\text { by foreigners (not just immigrants) are a threat. }\end{array}$ & 14 & 19 \\
\hline $\begin{array}{l}\text { The health care provides vaccines, which should prevent infectious diseases most } \\
\text { immigrants suffer from. }\end{array}$ & 14 & 20 \\
\hline $\begin{array}{l}\text { Immigrants have a sense of cleanliness, yet we can't avoid the accumulation of } \\
\text { garbage left by hundreds of wandering people. }\end{array}$ & 10 & 0 \\
\hline $\begin{array}{l}\text { I am not afraid of the epidemic. Europeans are vaccinated. Only tourists should be } \\
\text { particularly aware of the risks. }\end{array}$ & 5 & 0 \\
\hline Each person has a different immune system, not every refugee will be sick. & 4 & 0 \\
\hline
\end{tabular}

\section{Conclusions}

1. Migration of insects should be the interdisciplinary subject of lessons not only in the context of the role of insects in nature, but also in human economy and health.

2. On the one hand movement, migration of infected insects influence the geographical distribution of pathogenic organisms, on the other hand, physiological and behavioral effects of such infections affect the population dynamics of migrants. That relation should be depicted to students. The effects of various pathogens on the migrations of animals are studied for the last several years, but much remains to be discovered. In recent times, insects have attempted to compensate for the deficit in the knowledge of society through projects and national and international programs. But this is not enough, to affect social attitudes and increasing knowledge about it.

3. There are positive correlations between the messages of students - future teachers from the scope of the diseases spread through insects, and their negative attitudes towards the accommodation of refugees to European countries.

4. Participants of the research recognized the arrival of immigrants to Europe as unfounded and dangerous. In their opinion, the adoption of immigrants will be a threat of epidemics of diseases which Europe has never had to deal with. In their view, such an approach to the problem of refugees is a protection against the massive influx into Europe.

5. Students are concerned about the influx of so many groups of immigrants into Europe.

6. Both supporters and opponents of the emergence of immigrants in Europe partially blame media for disinformation of the society. Students expressing pro-immigrant attitudes claim that the media arouse unnecessary concerns about the spread of bacteria, viruses and fungi. Students of the anti-immigrant attitudes accuse the media of idealizing immigrants and concealing from the public the true information, including cultural motivation of their influx into Europe, as well as concealing the risk of outbreak of diseases, which are not characteristic for Europe.

\section{Recommendations}

\subsection{Migrations of Insects}

Migration of insects is still a little understood issue. It should be the subject of lessons in the context of the role of insects in nature and the human economy, and the impact 
on the health, and lives of people. It is worth emphasizing that the insects are the most numerous and economically important group of land migrants, but in contrast to vertebrates, most species are too small for an individual to track. The small size of the body, as well as their short life cycles, makes it difficult to conduct a regular observation [10]. Migration of insects is not only escape from the old habitat, but also affects the reproduction and colonization of new territories [13] [14].

In connection with climate changes in recent years, we should also point out that an important factor in the migration of many insects is the weather [15]. Recent studies of behavior of the migrant insects, have shown that their migration is not only influenced by wind, but also seasonal changes in the environment, climatic differences between regions and evolutionary drivers (evolutionary drivers) ([10]. There has been considerable progress in understanding evolutionary trends, environmental strategies and their consequences for the population dynamics of these migrants. Especially noteworthy are the newly documented examples of the benefits of being in a "continuous" movement, such as increasing the reproductive potential and thus increasing the chances of survival of the species, the lower the threat of predators, parasites and pathogens infection [11]. Despite these potential, benefits resulting from insects' migration over long ranges (distance) there is always a potential risk of death [40]. Besides, although the migrants occupying new habitat (environment) can thus avoid predators and parasites, but they can also be a source of parasites that can infect local populations [5].

\subsection{Risks Caused by Insects}

Curricula science should be more widely taken into account, that with the development of trade, tourism, climate changes and improvement of means of transport, the rate of movement of organisms has increased. Those new environmental conditions affect changes in biodiversity, cause economic losses and may threaten the health of humans and animals. They are invasive species. Invasive species can cause disturbances in local stable biocoenosis, and they make a threat to the economy and human health [31]. They compete with native species for food and habitat. They can completely change the structure of valuable habitats, and even the functioning of entire ecosystems.

Still is not sufficiently emphasis on different natural and social phenomena during the educational classes. For example, the severity of the introduction in the second half of the twentieth century caused a global threat to biodiversity comparable to the disappearance of natural environments, e.g. as a result of tropical deforestation. Very often invasive species do not encounter much resistance of the new areas of the environment; realize their high reproductive potential and their populations reach a large number, for example: horse chestnut leaf miner Cameraria ohridella. By this, they become both ecologically and economically problematic. For the production of agricultural foreign species for the country they are a huge threat and can cause crop losses for large areas. A classic example of Colorado potato beetle (Leptinotarsa decemlineata), which threatens the annual appearance of the potato crop. This pest left without eradication could reduce crop yields several dozen per cent. Foreign species are a threat to horticultural crops, forestry, and stored food products. Thus, preventing the invasion of foreign species is extremely important. Expenditure on detection and eradication is high [29]. Reducing the number of hours at schools on natural science subjects, led to the elimination of the content (they were presented in the program in the $80 \mathrm{~s}$ and early 90s) and failure in observing appropriate interspecific interactions.

Lack of professional sources of school knowledge about invasive species, which can be a reservoir of parasites, pathogens and their carriers and by them, they infect local populations. And there are already documented examples of invasive species which compete with native species "bringing with them infectious diseases", which are better tolerated bringing with them infectious disease agents that they themselves are better able to tolerate; a form of 'apparent competition [34]. Such an example may be introduced to Europe, Asian ladybird Harmonia axyridis (Asian harlequin ladybird). The Asian ladybird is hosting parasitic organism of the genus Nosema of the microsporids group that is tolerated by this species of insects because it produces antimicrobial alkaloid called harmony. However, this pathogen injected into European ladybird (native European Coccinella ladybirds) is lethal for it [38]. Whether mortality and a significant reduction in the population of European ladybird are only caused by the mikrosporids, has not been clearly confirmed yet. Perhaps there are other mechanisms that cause decline of European ladybirds [39].

On the one hand movement, migration of infected host insects influence the geographical distribution of pathogenic organisms, on the other hand, physiological and behavioral effects of such infections affect the population dynamics of migrants. That relation should be depicted to students. This may lead to a complicated relationship between the migration of pathogens and insects. The effects of various pathogens on the migrations of animals are studied for the last several years, but much remains to be discovered [1] [23].

Migrations of insects are significant due to the fact that among them is both useful species and hostile for us. Useful species of insects produce honey, wax, silk, pollinate crops, destroy weeds -preying on them, constitute the "service of sanitation" by eating dead plants and animals. Insects and their products are used in medicine 
(the venom of bees and ants), are predators and parasites snails, insects and mammals harmful to plants. Hostile species are plant pests and stored food products, causing huge economic losses. They have a great impact on our health and life. People are concerned about their presence: sting, parasitize on/in the human body and domestic animals, transmit plant pathogens (viruses, fungi, bacteria, mycoplasma), carry diseases in humans and animals, often leading to sickness at work and even death. The most dangerous insect disease vectors are: mosquitoes, flies, lice, fleas and cockroaches (Tables 8 i 9).

Table 8. Human and animals diseases transmitted by insects (based on: [7])

\begin{tabular}{|l|l|l|l|}
\hline Disease & Bestad & Wector & Pathogen \\
\hline malaria & people & mosquitoes & protozoan \\
\hline West Nile fever & people & mosquitoes, black flies & virus \\
\hline yellow fever & $\begin{array}{l}\text { people, monkeys, } \\
\text { rodents }\end{array}$ & mosquitoes & virus \\
\hline filariasis & people & mosquitoes & nematode \\
\hline African meningitis & people & tze tze fly & protozoan \\
\hline brain inflammation & people, horses, birds & mosquitoes & virus \\
\hline tularemia & people, rodents, birds & fleas, louses & bacteria \\
\hline spotted typhus & people & clothes louses & Rickettsia \\
\hline pestilence & people, rodents & fleas & bacteria \\
\hline dysentery & people & flies & amoeba, bacteria \\
\hline typhoid & people & flies & bacteria \\
\hline myxomatosis & rabbits & horseflies, mosquitoes & virus \\
\hline anthrax & people, animals & horseflies & bacteria \\
\hline
\end{tabular}

Table 9. Examples of human and amimals pathogens quick mechanically transmitted by vectors [9]

\begin{tabular}{|c|c|c|c|}
\hline Wector & Pathogen & Disease & Bestad \\
\hline cockroaches & bacteria & salmonellosis & people \\
\hline flies & $\begin{array}{l}\text { bacteria } \\
\text { protozoan } \\
\text { bacteria } \\
\text { protozoan }\end{array}$ & $\begin{array}{l}\text { cholera, typhoid, tuberculosis } \\
\text { amoebiasis } \\
\text { dysentery, digestive tract inflammation } \\
\text { African trypanosomiasis }\end{array}$ & $\begin{array}{l}\text { people } \\
\text { people } \\
\text { people } \\
\text { people }\end{array}$ \\
\hline horseflies, mosquitoes & bacteria & tularemia & people, hares, rabbits \\
\hline
\end{tabular}


In recent times, insects have attempted to compensate for the deficit in the knowledge of society through projects and national and international programs. But this is not enough, to affect social attitudes.

Examples worth adapting to school programs include:

1. Cosmopolitan housefly (Musca domestica) concerned human and animals with their presence, moving around during the day. It wakes us sitting on our body and releasing irritating humming sound. In addition, it mechanically transfers, on its body and in the gastrointestinal tract, all pathogens and pathogens of many pathogenic micro- organisms. It is an important vector of pathogens because it can fly many kilometers without a break in search of food and praying. It leaves feces with pathogens, parasites. As it is assessed by De Jesusi et al. [12] each landing of a fly on a clean surface remains $0.1 \mathrm{mg}$ of food and fecal bacteria. Flies carry: salmonellosis, typhoid, dysentery, typhoid, tuberculosis, polio (poliomyelitis), several species of nematodes, and even lice (Haematopinus suis) [33] [19]. For example, tubercle bacilli can survive in the gastrointestinal tract 16 days and further in the faces 13 days. Typhus pathogen survives 6 days and in feces 2 days. In Iran were determined pathogens which were found on the fly, and all of the above pathogens were detected [25].

In Germany and Canada are also described cases of allergy to the presence itself of many flies in the room. Some people respond only to allergens of fly's developmental stages (usually rhinitis), and did not react to other arthropods [36] [18] [35]. Flies can also cause watery eyes and conjunctivitis [41].

2. Spreading mosquitoes are vectors of many serious human diseases. In tropical countries annually, mosquitoes kill hundreds of thousands of people, especially children. Malaria is the most common infectious disease in the world that is carried by the female mosquitoes Anopheles genus. Due to global warming, globalized trade and the development of tourism at least three dangerous pathogens, which were spread by mosquitoes, can extend the range of their occurrence in countries of Central and Eastern Europe. They are West Nile fever virus, hemorrhagic fever Dengi and heartworms Dirofilaria causing dirofilariasis.

West Nile virus in France is mainly transmitted by the Culex modestus ([4]) and D. immitis is carried by different species of mosquitoes. For many years Asian mosquitoes Aedes japonicusi Stegomyia Albopicta were considered to be exotic insects in Europe. Currently, already they have found a home in Germany, and it is only a matter of time that they will spread in Europe (http://dw.com/p/16mSb). Mosquitoes can carry viruses: Zika, yellow fever encephalitis.

It is also necessary to introduce into education programs and deepen the knowledge about the new virus. For example:

The zika virus (ZIKV) has been detected in representatives of the mosquito species Aedes africanus in
Africa, Aedes aegypti in Malaysia [24]. More recent studies have found it also in Aedes apicoargenteus Aedes lutepcephalus, Aedes vitattus and Aedes furcifer [17]. It can also carry Aedes albopictus that occurs in the US [42]. The virus that causes tropical disease called zika fever. Infection with this virus is particularly dangerous for pregnant women because it can cause fetal microcephaly. It can also cause Guillain-Barre syndrome, which manifests itself with paralysis. The zika virus was first identified in Uganda in the 40s XX century, in herds of macaques living in forest Zika, hence derives its name. Since then they spread to the central and western part of Africa. It is also present in Asia the Pacific region. In 2014, the virus was found in South and Central America, and in 2015 in Brazil and in the United States. Scientists suspect that perhaps the virus crossed the Pacific Ocean along with the fans which were going to the FIFA World Cup in Brazil, which took place in 2014 [43].

Usually a mosquito bite is just an itchy red spot on the skin, which disappears after a few days. But there are also described cases of allergic reactions in humans sensitized to allergens in saliva of mosquitoes. These include, for example, popular urticaria, extensive reddened itchy swellings, asthma, damage bleeding, swelling of the vascular-nervous. The mosquito saliva distinguished more than 20 proteins and some of them are allergens [2] [8].

Strong and sometimes massive occurrences of different species of harmful insects should make us realize how dangerous any negligence or ignorance of humans is.

\section{REFERENCES}

[1] Altizer, S., Bartel, R., \& Han, B. (2011). Animal migration and infectious disease risk. Science, 331, 296-302.

[2] Arlian, L. (2002). Arthropod allergens and human health. Annual Review of Entomology, 47, 395-433.

[3] Babbie, E. (2005). Badania społeczne w praktyce. Warszawa: PWN.

[4] Balenghien, T., Fouque, F., Sabatier, P., \& Bicout, D. (2006). Horse, bird and human-seeking behavior and seasonal abundance of mosquitoes in the West Nile virus focus of southern France. Journal of Medical Entomology, 43, 936-46.

[5] Bauer, S. \& Hoye, B. (2014). Migratory animals couple biodiversity and ecosystem functioning worldwide. Science, 344 (6179), 1242552.

[6] Bilewicz, M. (2015). Kryzys uchodźczy jako kryzys postaw, Academia, magazyn PAN, wydanie specjalne, 8-12. Warszawa: PAN.

[7] Boczek, J. \& Lewandowski M. (2016). Nauka o szkodnikach roślin uprawnych. Warszawa: Wyd. SGGW.

[8] Brewczyński, P. (2006). Uczulenia na owady. Alergia, 3, 35-41. 
[9] Buczek, A. \& Boczek, J. (2011). Owady i roztocze jako wektory patogenów. In A. Buczek, \& C. Błaszak (Eds.), Stawonogi. Pasożyty człowieka i zwierząt, 79-93, Lublin: AKAPIT.

[10] Chapman, J., Reynolds, D., \& Wilson, R. (2015). Long-range seasonal migration in insects: mechanisms, evolutionary drivers and ecological consequences. Ecology Letters, 18, 287-302.

[11] Colautti, R., Ricciardi, A., Grigorovich, I., \& Maclsaac, H. (2004.) Is invasion success explained by the enemy release hypothesis? Ecology Letters, 7, 721-733.

[12] De Jesus, A., Olsen, A., Bryce, J., \& Whiting, R. (2004). Quantitative contamination and transfer of Escherichia coli from foods by houseflies, Musca domestica L. (Diptera, Muscidae). Journal Food Microbiology, 93, 259-262.

[13] Dingle, H. ed. (1978). Evolution of insect migration and diapause. New York: Springer-Verlag.

[14] Dingle, H. \& Drake, V.A. (2007). What is migration? Bioscience, 57, 113-121.

[15] Drake, V.A. \& Farrow, R. (1988). The influence of atmospheric structure and motions on insect migration. Annual Review of Entomology, 33, 183-210.

[16] Drake, V.A. \& Russell Reynolds D. (2012). Radar Entomology: Observing Insect Flight and Migration. Wallingford, UK: CABI.

[17] Duffy, M., Hancock, T., Powers, W.T., Kool, A., Lanciotti, J., Pretrick, R., Marfel, M., Holzbauer, M., Dubray, S., Guillaumot, C., Griggs, L., Bel, A., Lambert, M., Laven, A., Kosoy, J., Panella, O., Biggerstaff, A., Fischer, B., \& Hayes, E. (2009). Zika Virus Outbreak on Yap Island, Federated States of Micronesia. The New England Journal of Medicine, 360 (24), 2536-2543.

[18] Focke, M., Hemmer, W., Wohrl, S., Goetz, M., Jarisch, R., \& Kofler, H. (2003). Specific sensitization to common housefly (Musca domestica) not related to insect pan allergy. Allergy, 58(5), 448-451.

[19] Forster, M., Klimpel, S., \& Sievert, K. (2009). The house fly (Musca domestica) as a potential vector of metazoan parasites caught in a pigpen in Germany. Veterinary Parasitology, 160, 163-167.

[20] Głowaciński, Z., Okarma, H., Pawłowski, J., \& Solarz, W. eds. (2011). Gatunki obce w faunie Polski. Kraków: Instytut Ochrony Przyrody PAN w Krakowie.

[21] Gressit, J.L. (1961). Problems in the zoogeography of Pacific and Antarctic insects. Pacific Insect Monograph, 2, $1-94$.

[22] Gressit, J.L., \& Yoshimoto, C.M. (1963). Dispersal of animals in the Pacific. In J. L. Gressitt (Ed.), Pacific basin biogeography, 283-292, Bishop Museum, Press. Honolulu.

[23] Hall, R., Altizer, S., \& Bartel, R. (2014). Greater migratory propensity in hosts lowers pathogen transmission and impacts. Journal of Animal Ecology, 83, 1068-1077.

[24] Lanciotti, R., Kosoy, O., Laven, J., Velez, J., Lambert, A., Johnson, A., Stanfield, S., \& Duffy, M. (2008). Genetic and Serologic Properties of Zika Virus Associated with an Epidemic, Yap State, Micronesia. 2007. Emerging
Infectious Diseases, 14 (8), 1232-1239.

[25] Kassiri, H., Akbarzadeh, K., \& Ghaden, A. (2012). Isolation of pathogenic bacteria on the house fly, Musca domestica L. (Diptera:Muscidae), body surface in Ahwaz hospitals, Southwestern Iran. Asian Pacific Journal of Tropical Biomedicine, 2, 1116-1119.

[26] Kostrowicki, A.S. (1999). Geografia biosfery. Warszawa: Wydawnictwo Naukowe PWN.

[27] Lundberg, S. (1995). Catalogus coleopterorum Sueciae. Naturhistoriska Riksmuseet. Entomologiska Föreningen. Stockholm.

[28] Nawrot, J. (2010). Inwazyjny szkodnik pomidora w Europie. Hasło ogrodnicze, 10, 84-85.

[29] Nawrot, J., \& Lipa J. (2012). Znaczenie obcych gatunków inwazyjnych w ochronie roślin. Progress in Plant Protection, $52(2), 449-452$.

[30] Okólski, M. (2015). Europa: zmęczona ziemia obiecana, Academia, magazyn PAN, wydanie specjalne, 4-7, Warszawa: PAN

[31] Pimentel, D. (2002). Biological invasions; economics and environmental costs of alien plant, animal, and microbe species. CRC Press, Boca Raton, London, New York, Washington DC.

[32] Prądzyńska, A. (1988). Transport produktów żywnościowych i nasiennych główną drogą rozprzestrzeniania się owadów magazynowych. Wiadomości Entomologiczne, 8 (1-2), 47-60.

[33] Sanders, D. (1940). Musca domestica a vector of bovine mastitis (preliminary report). Journal of the American Veterinary Medical Association, 97, 120-112.

[34] Strauss, A., White, A., \& Boots, M. (2012). Invading with biological weapons: the importance of disease-mediated invasions. Functional Ecology, 26, 1249-1261.

[35] Tas, E., Jappe, U., Beltraminelli, H., \& Bircher A. (2007). Occupational inhalant allergy to the common house fly (Musca domestica). Hautarzt, 58, 156-160.

[36] Tee, R., Gordon, D., Lacey, J., Nunn, A., Brown, M., \& Taylor, A. (1985). Occupational allergy to the common house fly (Musca domestica): use of immunologic response to identify atmospheric allergen. Journal of Allergy and Clinical Immunology, 76, 826-831.

[37] Udvardy, M.D.F. (1978). Zoogeografia dynamiczna. Warszawa: PWN.

[38] Vilcinskas, A., Stoecker, S., Schmidtberg, H., Rohrich, C., \& Vogel, H. (2013a). Invasive Harlequin ladybirds carry biological weapons against native competitors. Science, $340,862-863$

[39] Vilcinskas, A., Stoecker, S., Schmidtberg, H., Rohrich, C., \& Vogel, H. (2013b). Response to comments on "Invasive Harlequin ladybirds carry biological weapons against native competitors". Science, 341, 1342.

[40] Ward, S.A., Leather, S., Pickup, J., \& Harrington, R. (1998). Mortality during dispersal and the cost of host-specificity in parasites: how many aphids find hosts?. Journal of Animal Ecology, 67, 763-773. 
[41] Wahl, R., \& Fraedrich, J. (1997). Occupational allergy to the housefly (Musca domestica). Allergy, 52, 236-238.

[42] Centers for Disease Control and Prevention: Surveillance and Control of Aedes aegypti and Aedes albopictus in the United States (ang.). U.S. Department of Health \& Human Services. Retrieved from http://dw.com/p/16mSb; Accesse d 20 August 2019.

[43] http://www.poradnikzdrowie.pl/zdrowie/choroby-zakazne/ wirus-zika-moze-powodowac-maloglowie-objawy-zakazen ia-wirusem-zika_43335.html; Accessed 20 August 2019. 